\title{
Taxonomic synopsis of Leguminosae subfamilies Cercidoideae, Detarioideae, and Dialioideae in the National Forest of Caxiuanã, Pará, Brazil

\author{
Sinopse taxonômica das subfamílias Cercidoideae, Detarioideae e Dialioideae \\ (Leguminosae) na Floresta Nacional de Caxiuanã, Pará, Brasil
}

\author{
Catarina Silva de Carvalho' (1) | Rafael Barbosa Pinto" (1) | Marli Pires Morim' (1) | João Ubiratan Moreira dos Santos ${ }^{\text {III }}$ (1) \\ Instituto de Pesquisas Jardim Botânico do Rio de Janeiro. Rio de Janeiro, Rio de Janeiro, Brasil \\ "Universidade Federal de Goiás. Instituto de Ciências Biológicas. Departamento de Botânica. Programa de Pós-Graduação em \\ Genética e Biologia Molecular. Goiânia, Goiás, Brasil \\ I'IUniversidade Federal Rural da Amazônia. Instituto de Ciências Agrárias. Belém, Pará, Brasil
}

\begin{abstract}
We conducted a floristic study in the National Forest of Caxiuanã (FLONA Caxiuanã) located in the state of Pará, Brazil, in the municipalities of Portel and Melgaço. This forest is characterized by Amazonian physiognomies such as lowlands, seasonally flooded areas (várzea and igapó), Amazonian white-sand scrub (campinarana) and secondary forests. This article provides a taxonomic synopsis of the members of the Leguminosae subfamilies Cercidoideae, Detarioideae, and Dialioideae that occur in the FLONA Caxiuanã, based on herbarium studies and field expeditions. Nineteen species were catalogued, including two members of Cercidoideae, 16 of Detarioideae, and one of Dialioideae. The species of Cercidoideae from FLONA Caxiuanã are restricted to the Amazon forest, and one of them is exclusive to the Brazilian Amazon. Of the species of Detarioideae, $81.25 \%$ are restricted to the Amazon forest and $25 \%$ are exclusive to the Brazilian Amazon. The single species of Dialioideae is restricted to the Amazon forest. The most species-rich genera belong to Detarioideae: Macrolobium (six species). The two members of Cercidoideae and the only Dialioideae species occur in terra firme forest; the $56.25 \%$ species of Detarioideae occur in igapó forests. We include an identification key for the species presented in the synopsis, with illustrations, diagnoses, and taxonomic comments for all catalogued species.
\end{abstract}

Keywords: Amazon. Fabaceae. FLONA. Flora. Taxonomy.

Resumo: $\bigcirc$ estudo foi conduzido na Floresta Nacional de Caxiuanã (FLONA Caxiuanã), localizada no Norte do Brasil, estado do Pará, nos municípios de Portel e Melgaço, abrangendo os tipos de vegetação das florestas de Terra Firme, Várzea, Igapó, Campinarana e Capoeira. O objetivo foi realizar uma sinopse taxonômica acerca das subfamílias de Leguminosae Cercidoideae, Detarioideae e Dialioideae, que ocorrem na FLONA Caxiuanã, baseada em consultas a herbários e em expedições de campo. Foram tratadas 19 espécies, sendo que destas duas são de Cercidoideae, 16 são de Detarioideae e uma de Dialioideae. As duas espécies de Cercidoideae da FLONA Caxiuanã são restritas à Amazônia e uma destas com ocorrência exclusiva na Amazônia brasileira; das espécies de Detarioideae, 81,25\% são restritas à Amazônia e destas, 25\% ocorrem exclusivamente na Amazônia brasileira; a única espécie de Dialioideae é restrita à Amazônia. $\bigcirc$ gênero mais representativo pertence à subfamília Detarioideae: Macrolobium (com seis espécies). As duas espécies de Cercidoideae e a única espécie de Dialioideae ocorrem em florestas de Terra Firme; as espécies de Detarioideae ocorrem em sua maioria $(56,25 \%)$ nas florestas de Igapó. A presente sinopse inclui uma chave de identificação para as espécies, ilustrações, diagnoses e comentários para cada espécie.

Palavras-chave: Amazônia. Fabaceae. FLONA. Flora. Taxonomia.

CARVALHO, C. S., R. B. PINTO, M. P. MORIM \& J. U. M. SANTOS, 2021. Taxonomic synopsis of Leguminosae subfamilies Cercidoideae, Detarioideae, and Dialioideae in the National Forest of Caxiuanã, Pará, Brazil. Boletim do Museu Paraense Emílio Goeldi. Ciências Naturais 16(1): 73-88. DOI: http://doi.org/10.46357/bcnaturais.v16i1.437.

Autora para correspondência: Catarina Silva de Carvalho. Rua Otávio Cabral, 550 - Petrópolis. Manaus, AM, Brasil. CEP 69067-370 (carvalho_catarina@outlook.com).

Recebido em 13/10/2020

Aprovado em 18/02/2021

Responsabilidade editorial: Ana Kelly Koch
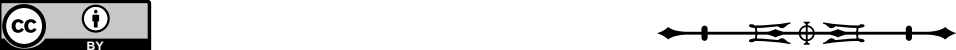


\section{INTRODUCTION}

Floristic studies are essential to improve knowledge of the plant variety of a region, especially in the Amazon forest, where the diversity of species is still underestimated (e.g., Nogueira et al., 2009; Forzza et al., 2012; ter Steege et al., 2013; Loyola et al., 2014; Cardoso et al., 2017; BFG, 2018). The legumes family is among the most important of Angiosperm, because of its diversity, ecology, and economic uses, and its representatives can be found in many different ecosystems (Lewis et al., 2005; LPWG, 2017). Leguminosae is currently composed of six subfamilies: Caesalpinioideae DC., Cercidoideae LPWG, Detarioideae Burmeist., Dialioideae LPWG, Papilionoideae DC., and Duparquetioideae LPWG, the only one without species in Brazil (LPWG, 2017). In Brazil, Leguminosae is represented by 220 genera and 2,852 species, of which 1,139 occur in the Amazon domain (BFG, 2015, 2018).

Several combined characteristics are used as diagnostic for the subfamilies, such as pinnate, uni- or bifoliolate leaflets, and the presence of a mucro at the apex or between the leaflets for Cercidoideae; resinproducing capability, intrapetiolar stipule, paripinnate leaves, small number of leaflets, frequently petaloid bracts, and valvar or imbricate petals for Detarioideae; and imparipinnate leaves, opposite leaflets, tyrso inflorescences, and drupaceous or samaroid legumes for Dialioideae (LPWG, 2017).

The National Forest of Caxiuanã (henceforward FLONA Caxiuanã) is currently managed by the governmental agency Instituto Chico Mendes de Conservação da Biodiversidade (ICMBio) (ICMBio, 2020). About 100 species of legumes are estimated to inhabit this national forest (Carvalho, 2016). Several taxonomic studies have treated subfamilies of Leguminosae from the FLONA Caxiuanã; for example, Carvalho et al. (2020) studied 53 species of the subfamily Caesalpinioideae; Bonadeu \& Santos (2013) studied the tribe Ingeae (subfamily Caesalpinioideae, Mimosoid clade); and
Félix-da-Silva et al. (2013) focused on the species of Macrolobium Schreb. (subfamily Detarioideae).

This study aims characterize the subfamilies species Cercidoideae, Detarioideae, and Dialioideae of FLONA Caxiuanã, complementary to the studies of Bonadeu \& Santos (2013), Félix-da-Silva et al. (2013), Carvalho (2016), and Carvalho et al. (2020), as well as contribute to knowledge of the plant biodiversity of the FLONA Caxiuanã, the first protected reserve in the Amazon forest (ICMBio, 2020).

\section{MATERIAL AND METHODS}

The FLONA Caxiuanã is situated in the municipalities of Portel (01 56' 09" S, 50 49' 15" W) and Melgaço ( $01^{\circ} 48^{\prime} 21.44^{\prime \prime}$ S, 50 43'00" W) in the state of Pará, Brazil, and covers $317,946.37$ ha (Figure 1). It includes the Amazonian physiognomies of lowlands (terra firme), seasonally flooded areas (várzea and igapó), Amazonian white-sand scrub (campinarana), and secondary forests (capoeira; Figures 2A-2E). For a complete characterization of the area, see Carvalho et al. (2020).

Three field expeditions, lasting one month each, were conducted during August 2014 and July 2015 in different parts of the area (Figure 1). The collections followed the techniques of Fidalgo \& Bononi (1984). The material collected was deposited in the MG, IAN and RB herbaria (acronyms according to Thiers, 2021). These herbaria were also consulted for additional collections from the area.

The genera and species were identified using previous taxonomic revisions and identification keys (Ducke, 1949; Cowan, 1953; Dwyer, 1958; Koeppen \& Iltis, 1962; Lee \& Langenheim, 1975; Silva, 1976; Vieira, 1990; Wunderlin, 1998; Martins-da-Silva et al., 2008; Félix-da-Silva et al., 2013) and through comparison with virtual collections (INCT, 2020; JSTOR, 2020; Reflora, 2020; Tropicos, 2020). The delimitation of the subfamilies follows LPWG (2017). For the species of Macrolobium we provide only taxonomic comments and distribution 


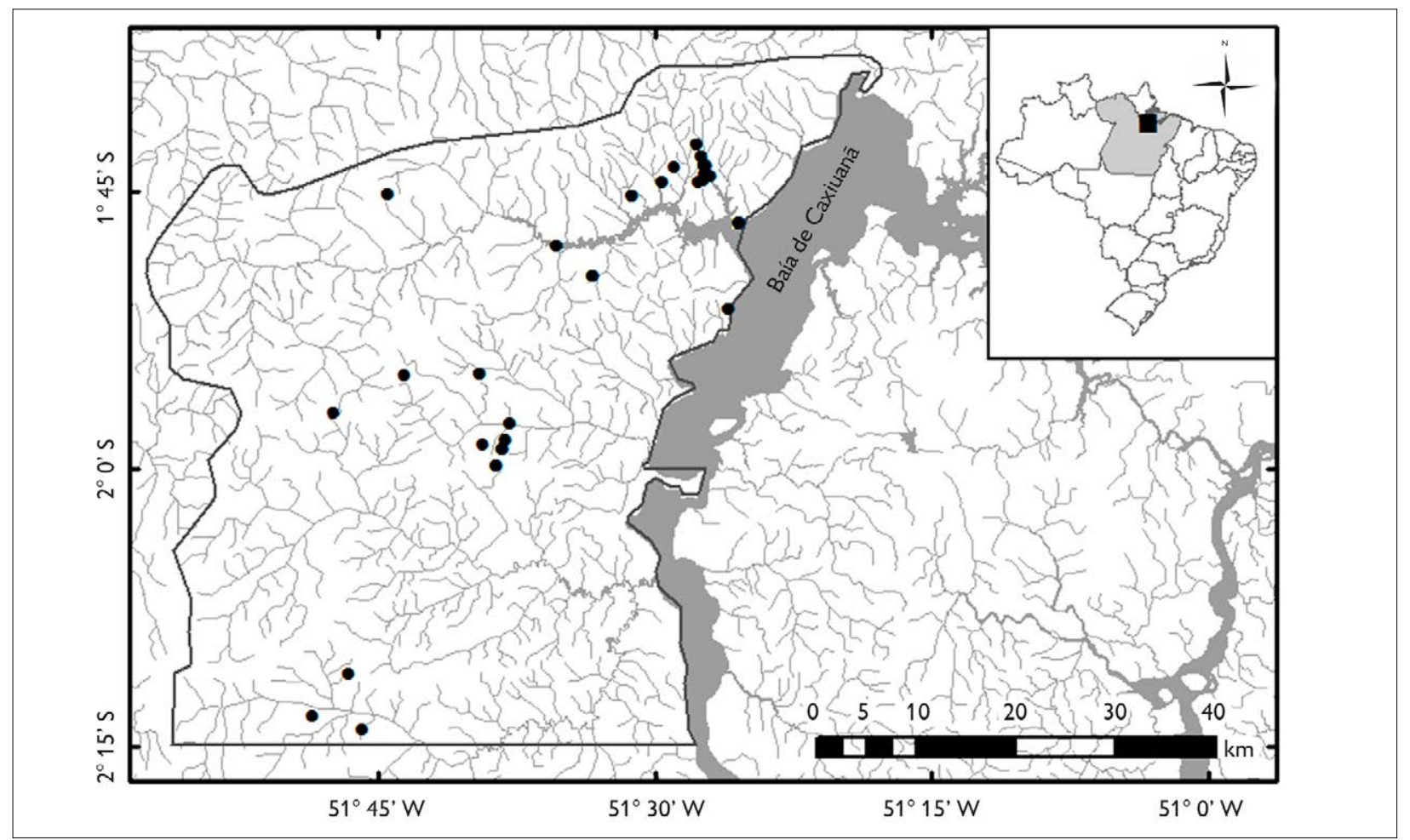

Figure 1. Map of FLONA Caxiuanã showing the points where were made the field expeditions. Map: Erlane J. Cunha (2015).

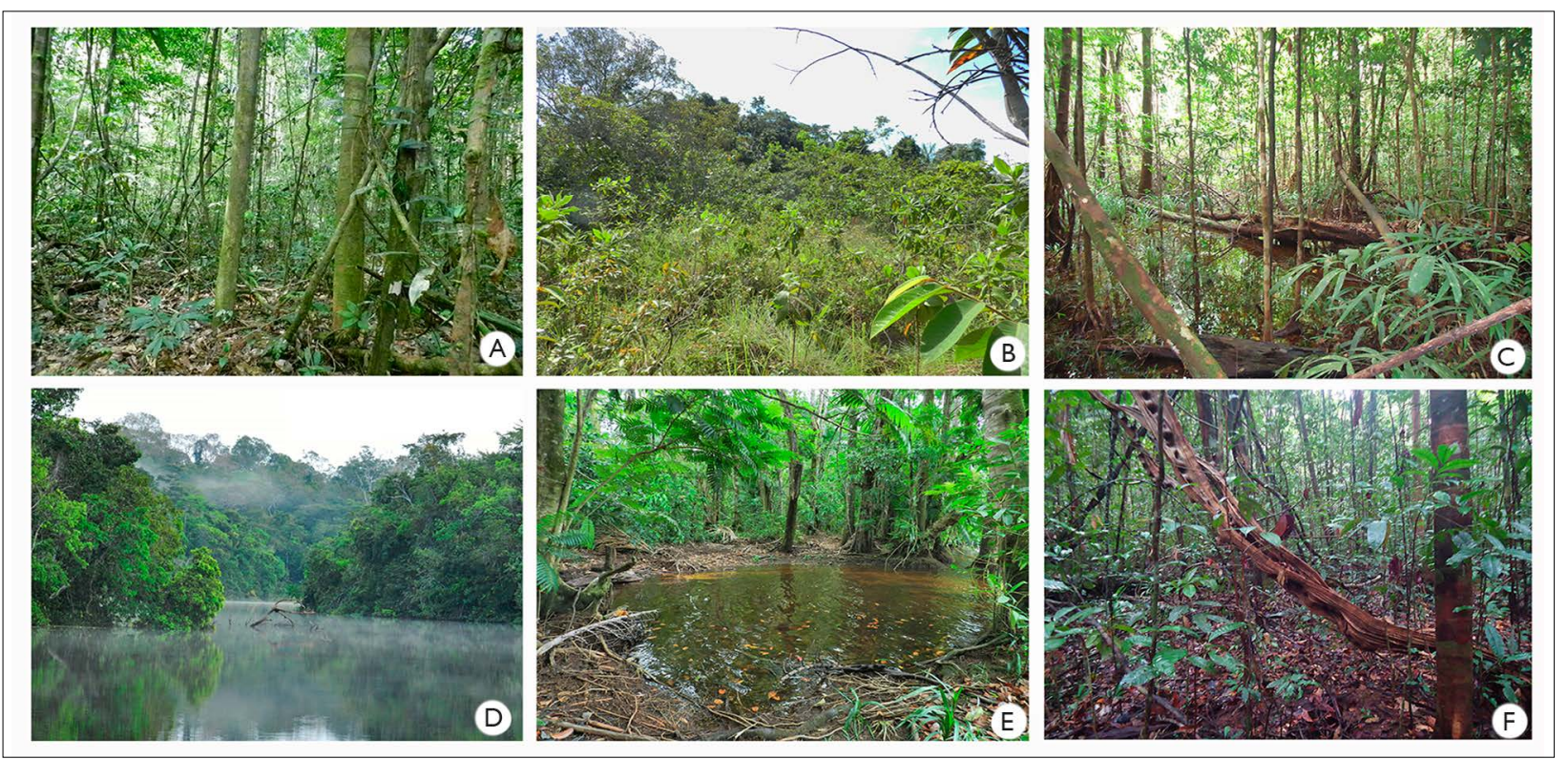

Figure 2. A-E) Characterization of the Amazonian physiognomies of FLONA Caxiuanã: A) terra firme; B) campinarana; C) igapó; D) igapó river; E) várzea; F) the trunk of Schnella rutilans, that are commonly recognized as 'escada de macaco', in the terra firme forests. Photos: Catarina S. Carvalho (2015).

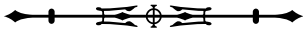


information, since descriptions and illustrations can be found in Félix-da-Silva et al. (2013). The accepted names follow Flora do Brasil 2020 (2021). Author names follow Brummitt \& Powell (1992), the morphological terminology for venation patterns follows Ellis et al. (2009), for fruits and seeds follows Barroso et al. (1999), and for other structures follows Bentje (2010). When necessary, additional materials were used for description of reproductive characters.

\section{RESULTS AND DISCUSSION}

Nineteen species were catalogued (Table 1). The most species-rich subfamily was Detarioideae (16 species), followed by Cercidoideae (two species) and Dialioideae (one species). Macrolobium was the largest genus of Detarioideae (six species), followed by Crudia
Schreb. (three species), Cynometra L. (two species), Hymenaea L. (two species) and Copaifera L. (two species). Cercidoideae was represented by Schnella Raddi (two species) and Dialiodeae was represented by Martiodendron Gleason (one species).

According to the databases of BFG (2015) and Cardoso et al. (2017), the two species of Schnella are restricted to the Amazon domain and Schnella rutilans (Spruce ex Benth.) Pittier is endemic to the Brazilian Amazon. Of the species of Detarioideae, $81.25 \%$ are restricted to the Amazon domain and 25\% are exclusive to the Brazilian Amazon. The single species of Dialioideae is restricted to the Amazon domain. The two species of Cercidoideae and the single of Dialioideae occur in terra firme forests; the species of Detarioideae occur mainly in igapó forests (56.25\%) (Table 1).

Table 1. List of the species of Leguminosae subfamilies, Cercidoideae, Detarioideae, and Dialioideae, that occur in the FLONA Caxiuanã, Pará, Brazil. Legends: * = restrict to Amazon; ** = restrict to the Brazilian Amazon; I = igapó; TF = terra firme; V = várzea.

\begin{tabular}{l|l|c}
\hline \multicolumn{1}{c|}{ Species } & Subfamily & Habitat \\
\hline Schnella rutilans** & Cercidoideae & $\mathrm{TF}$ \\
\hline Schnella splendens* & Cercidoideae & $\mathrm{TF}$ \\
\hline Copaifera duckei & Detarioideae & $\mathrm{TF}$ \\
\hline Crudia aequalis* & Detarioideae & $\mathrm{I}$ \\
\hline Crudia bracteata* & Detarioideae & $\mathrm{I}$ \\
\hline Crudia oblonga* & Detarioideae & $\mathrm{TF}$ \\
\hline Cynometra bauhiniaefolia & Detarioideae & $\mathrm{TF}$ \\
\hline Cynometra longicuspis** & Detarioideae & $\mathrm{V}$ \\
\hline Eperua bijuga* & Detarioideae & $\mathrm{TF}$ \\
\hline Hymenaea courbaril & Detarioideae & $\mathrm{TF}$ \\
\hline Hymenaea intermedia* & Detarioideae & $\mathrm{I}, \mathrm{V}$ \\
\hline Macrolobium angustifolium* & Detarioideae & $\mathrm{I}$ \\
\hline Macrolobium bifolium** & Detarioideae & $\mathrm{I}$ \\
\hline Macrolobium brevense** & Detarioideae & $\mathrm{TF}$ \\
\hline Macrolobium campestre var. arboreum*** & Detarioideae & $\mathrm{I}$ \\
\hline Macrolobium huberianum var. huberianum* & Detarioideae & $\mathrm{I}$ \\
\hline Macrolobium pendulum** & Detarioideae & $\mathrm{I}, \mathrm{V}$ \\
\hline Peltogyne venosa subsp. densiflora* & Detarioideae & $\mathrm{TF}$ \\
\hline Martiodendron parviflorum* & Dialioideae & \\
\hline
\end{tabular}

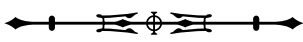


Identification key to the species of Cercidoideae, Detarioideae, and Dialioideae from FLONA Caxiuanã

1. Leaves apparently simple or bilobed 2 (Cercidoideae) Leaves notably pinnate

2. Branches smooth; leaves apparently simple or rarely slit until $1 / 3$ of the blade; hypanthium urceolate, striate Schnella rutilans

Branches striate; leaves bilobed, the slit until the base; hypanthium campanulate, smooth ..... Schnella splendens

3. Anthers poricidal, sagittate (Dialiodeae) Martiodendron parviflorum Anthers rimose, oblong (Detarioideae) 4

4. Leaves with 2 leaflets 5

Leaves with more than 2 leaflets. 12

5. Leaflets $2-9 \mathrm{~cm}$ width; fruit legume 6

Leaflets 1.5-4 cm width; fruits bacoid legumes or camara............................................................... 9

6. Leaflets with glands in upper and lower surface Peltogyne venosa subsp. densiflora Leaflets without glands

7. Leaflets elliptic, flaky; legume ovoid Macrolobium pendulum Leaflets lanceolate, falcate; legume elliptic, elliptic-obovoid, and oblongoid. 8

8. Leaflets lower surface with trichomes; ovary with trichomes only in the margins...... Macrolobium angustifolium Leaflets lower surface glabrous; ovary with tomentose surface Macrolobium bifolium

9. Flowers with hypanthium 4-5 mm long, nectariferous disc absent in the base of the corolla and stamens; fruit bacoid legume, no-resinous surface....

Flowers with hypanthium 12-15 mm long, nectariferous disc present in the base of the corolla and stamens; fruit camara with resinous surface

10. Leaflets with apex emarginate and caudate, 1 conspicuous vein Cynometra longicuspis Leaflets with apex emarginate-rounded, 3 conspicuous vein Cynometra bauhiniaefolia

11. Leaf rachis $0.7-1.1 \mathrm{~cm}$ long; leaflets elliptic-falcate, translucent glands presents in the blade; camara piriform or oblongoid, lustrous-brown, 8-15 $\times$ 4-6 cm; seeds 5-8 per fruit..... Hymenaea courbaril Leaf rachis ca. $0.3 \mathrm{~cm}$ long; leaflets oblong, without glands translucent glands in the blade; camara ovoid or rhomboid, opaque-brown, 6-7.5 $\times 3-4.5 \mathrm{~cm}$; seeds 1-3 per fruit. Hymenaea intermedia

12. Leaflets opposite; flowers differentiate into petals and sepals 13 Leaflets alternate; flowers no-differentiate into petals and sepals .................................................. 16

13. Glands present in the base of the leaflets; filaments fused Eperua bijuga Glands absent; filaments free

14. Leaflets $3-12 \times 2-6 \mathrm{~cm}$ Macrolobium campestre var. arboreum Leaflets $0.2-2 \times 0.1-0.6 \mathrm{~cm}$

15. Branch glabrous; leaflets discolorous, apex rounded; axis of inflorescence glabrous; legumes $2.5-3.5 \mathrm{~cm}$ width Macrolobium huberianum var. huberianum Branch covered by trichomes; leaflets concolorous, apex retuse or emarginate; axis of inflorescence covered with trichomes; legumes $3.5-4.5 \mathrm{~cm}$ width .Macrolobium brevense

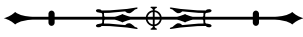


16. Leaflets 10 , venation craspedodromous; fruit ca. $3.1 \mathrm{~cm}$ long..... Copaifera duckei

Leaflets 5-8, venation brochidocromous; fruit 6-9.1 cm long 17

17. Leaves rachis $8-11.2 \mathrm{~cm}$ long; fruit legume ovoid or rhombic..... Crudia aequalis

Leaves rachis 4-6.2 cm long; legume oblongoid, obovoid or globoid. 18

18. Leaflets 8, oblong or obovate, apex rounded; ovary ca. $3 \mathrm{~mm}$ long, stipe tomentose........... Crudia oblonga Leaflets 5-7, ovate, apex attenuate; ovary ca. 8 mm long, stipe glabrous. Crudia bracteata

\section{CERCIDOIDEAE FROM FLONA CAXIUANÃ}

\section{Schnella Raddi, Quar. Piant. Nuov. Bras. 32. 1820}

Liana. Stipules sericeous, sessile. Leaves apparently simple or bilobed, leaflets without glands, ovate or oblong base rounded or cordate, apex acuminate, venation acrodromous. Flowers differentiate into sepals and petals, with urceolate or campanulate hypanthium, stamens 10, free filaments, anthers globose, rimose; staminodes absent; nectariferous disc absent; ovary oblongoid, ca. $3 \mathrm{~mm}$ long. Fruit legume, oblongoid, surface rugose. Seeds do not see.

\section{Schnella rutilans (Spruce ex Benth.) Pittier, Third} Conf. Interamer. Agric. Caracas 362. 1945

(Figures 3A-3B)

Branch smooth, sericeous; stipules ovate, ca $1.5 \times 2 \mathrm{~mm}$. Leaves simple, rarely slit until $1 / 3$ of the blade; leaflets ovate; base rounded, 6.3-12.7 $\times 5.1-7.3 \mathrm{~cm}$. Flowers with urceolate hypanthium, striate, ca. $8 \mathrm{~mm}$ long. Legumes ca. $7.5 \times 2.2 \mathrm{~cm}$.

Distribution: Colombia, Equador, Peru, Venezuela, and Brazil: Amapá, Pará, and Roraima (Wunderlin, 1998; BFG, 2015, 2018; Trethowan et al., 2015).

Specimens examined: Brazil. Pará: Melgaço, FLONA Caxiuanã, Estação Científica Ferreira Penna, "entre os rios Curuá e Puraquequara ao lado da torre de observação", 21.XI.1994, fl., A.S.L. Silva et al. 3116 (MG); Portel, FLONA Caxiuanã, Estação Científica Ferreira Penna, "trilha principal atrás da base física da FLONA ao plote 1 do TEAM", 174' 12" S, 51 45' 62" W, 18.II.2015, fl., C. Carvalho 259 (MG); Portel, FLONA Caxiuanã, Estação Científica Ferreira
Penna, "trilha atrás da base física da FLONA", $1^{\circ} 74$ ' 12" S, 51 45' 62" W, 13.II.2015, fr., C. Carvalho 255 (MG).

Schnella rutilans is restricted to the Amazon rain forest and occurs in all terra firme forests of the FLONA Caxiuanã. It is commonly known as 'escada de macaco', for its resemblance to stairs in the forest (Figure 2F). It differs from S. splendens (Kunth) Benth. by the leaflets generally entire, if slit, only up to $1 / 3$ of the blade; and by the flowers with an urceolate hypanthium (versus fully slit leaves and flowers with a campanulate hypanthium in S. splendens).

Schnella splendens (Kunth) Benth., J. Bot. (Hooker) 2(10): 97.1840 (Figures 3C-3D)

Branch striate, glabrescent; stipules deltate, ca. $1 \times 0.8 \mathrm{~mm}$. Leaves bilobed, the slit until the base; leaflets ovate or oblong; base cordate, 3-9 × 1.2-6 cm. Flowers with campanulate hypanthium, smooth, ca. $5 \mathrm{~mm}$ long. Legumes ca. 5-7.7 × 1.5-2 cm.

Distribution: Nicaragua, Panama, Colombia, Trinidad, Equador, Venezuela, and Brazil: in all Amazon forest, except in Tocantins (BFG, 2015, 2018; Trethowan et al., 2015).

Specimens examined: Brazil. Pará: Melgaço, FLONA Caxiuanã, "Estação Científica Ferreira Penna (plote 2 do Team)", $1^{\circ}$ 74' 23" S, 510 49' 43" W, 19.II.2015, fl., C. Carvalho 260 (MG); Portel, FLONA Caxiuanã, Estação Científica Ferreira Penna, "margem do rio Caxiuanã", $1^{\circ} 46^{\prime} 32$ " S, 51 28' 47” W, 02.IX.2014, fl., C. Carvalho 219 (MG).

Schnella splendens, as does S. rutilans, occurs in terra firme forests of the FLONA Caxiuanã, and is also commonly called 'escada de macaco' (Figure 2F). 
The diagnostic characters of S. splendens are treated in the above comments on S. rutilans.

\section{DETARIOIDEAE FROM FLONA CAXIUANÃ}

\section{Copaifera L. Sp. Pl. (ed. 2) 1: 557. 1762}

Copaifera duckei Dwyer, Brittonia 7(3): 163-164. 1951 (Figure 3E and complementary illustrations in Martins-da-Silva et al., 2008)

Trees ca. $40 \mathrm{~m}$ high. Branches striate, tomentose; stipules deltate, tomentose, sessile, ca. $1.9 \times 1 \mathrm{~mm}$. Leaves notably pinnate, paripinnate, rachis pubescent, ca. $10.5 \mathrm{~cm}$ long; leaflets 10, alternate, glands absent, falcate, base cuneate, apex attenuate, $5-9 \times 2-3.5 \mathrm{~cm}$, venation craspedodromous. Flowers differentiate into sepals and petals, campanulate hypanthium, ca. $3 \mathrm{~mm}$ long; stamens 10, free filaments, anthers rimose, oblong; staminodes absent; nectariferous disc absent; ovary oblongoid, ca. 2.5 $\mathrm{mm}$ long. Fruit legume, obovoid or oblique-oblongoid, surface rugose, no-resinous, ca. $3.1 \times 4.5 \mathrm{~cm}$. Seeds do not see.

Distribution: Bolivia and Brazil: Pará, Tocantins, Maranhão, Piauí, Ceará, Paraíba, Bahia, and Rio de Janeiro (BFG, 2015, 2018).

Specimens examined: Brazil. Pará: Portel, FLONA Caxiuanã, "plote 2 do TEAM", $1^{\circ}$ 74' 23" S, 51 49' 43" W, 19.II.2015, fr., C. Carvalho 262 (MG).

Additional specimen: Brazil. Pará: Bragança, "Sítio do Joca, Benjamim Constante, Arv. 05", 9.X.2004, fl., J.C.L. Oliveira 436 (IAN).

Copaifera duckei is distributed in Brazilian rain forests and Brazilian savannas (Cerrado), and is among the taller trees of terra firme forests of the FLONA Caxiuanã. Because of its habit, alternate leaflets, and the flowers not differentiated into sepals and petals, C. duckei is morphologically closest to Crudia aequalis Ducke. However, C. duckei is readily recognized by the number of leaflets (10), falcate, and the legume ca. $3.1 \times 4.5 \mathrm{~cm}$, and rugose surface (versus 7 leaflets, ovate or elliptic, 7-11 $\times$ 6-8 cm, and showy striate surface in C. aequalis).

\section{Crudia Schreb., Gen. Pl. 282. 1789}

Trees. Branches smooth or fissured; stipules do not see. Leaves notably pinnate, imparipinnate, rachis glabrous or sericeous; leaflets alternate, glands absent, venation brochidodromous. Flowers differentiate into petals and sepals, campanulate hypanthium; stamens 10, free filaments, anthers rimose, oblong; staminodes absent; nectariferous disc absent; ovary ovoid or oblongoid. Fruit legume, surface striate, no-resinous. Seeds do not see.

Crudia aequalis Ducke, Arch. Jard. Bot. Rio de Janeiro 3: 91.1922 (Figure 3F and complementary illustrations in Vieira, 1990)

Trees ca. $30 \mathrm{~m}$ high. Branches smooth. Leaves with glabrous rachis, 8-11.2 cm long; leaflets 7, ovate or elliptic, base cuneate, apex caudate, 5.5-11.3 $\times 2.1-4 \mathrm{~cm}$. Flowers with hypanthium ca. $1 \mathrm{~mm}$ long; ovary ovoid, tomentose, sessile, ca. $8 \mathrm{~mm}$ long. Legume ovoid or rhombic, 7-11 $\times 6-8 \mathrm{~cm}$.

Distribution: Colombia, Venezuela, and Brazil: Amazonas, Pará, and Amapá (Kearns, 1998; Ducke, 1949; BFG, 2015, 2018).

Specimens examined: Brazil. Pará: Melgaço, FLONA Caxiuanã, Estação Científica Ferreira Penna, "margem do rio Curuá", X.2015, fr., A.S.L. Silva et al. 3811 (MG); Melgaço, FLONA Caxiuanã, Estação Científica Ferreira Penna, "margem direita do rio Curuá, em direção ao rio Caxiuanã”, 17.XI.1994, fr., A.S.L. Silva et al. 3109 (MG); Melgaço, FLONA Caxiuanã, Estação Científica Ferreira Penna, "interflúvio Puraquequara - Tijucaquara", 10.VIII.2004, fr., A.S.L. Silva et al. 4320 (MG); Portel, FLONA Caxiuanã, Estação Científica Ferreira Penna, "trilha principal por trás da base física da estação", 1 1 71' 41" S, 51 45’ 33" W, 11.II.2015, fr., C. Carvalho 254 (MG).

Crudia aequalis occurs in the igapó forests of the FLONA Caxiuanã and is locally known as 'rim de paca' or 'gitirana'. It is morphologically close to C. bracteata Benth., 
from which it is distinguished by the leaflets $11.3 \mathrm{~cm}$ long, base cuneate, apex caudate, and ovoid or rhombic legumes (versus leaflets up to $7.5 \mathrm{~cm}$ long, base rounded, apex attenuate, and globoid legumes in C. bracteata).

Crudia bracteata Benth., J. Bot. (Hooker) 2(10): 101. 1840 (Figure 3G and complementary illustrations in Vieira, 1990)

Trees ca. $25 \mathrm{~m}$ high. Branches fissured. Leaves with glabrous rachis, 4-6.2 cm long; leaflets 5-7, ovate, base rounded, apex attenuate, $2.4-7.5 \times 1.2-3 \mathrm{~cm}$. Flowers with hypanthium ca. $10 \mathrm{~mm}$ long; ovary ovoid, glabrous, $8 \mathrm{~mm}$ long, stipe glabrous. Legume obovoid or globoid, $6-8.5 \times 3.5-4.5 \mathrm{~cm}$.

Distribution: Guiana Francesa and Brazil: Amazonas, Pará, and Amapá (Vieira, 1990; BFG, 2015, 2018; Reflora, 2020).

Specimens examined: Brazil. Pará: Melgaço, FLONA Caxiuanã, Estação Científica Ferreira Penna, "Rio Camuim, Projeto PELD”, 20.IX.2011, fr., L.C.B. Lobato \& L. Ferreira 4000 (MG); Portel, FLONA Caxiuanã, Estação Científica Ferreira Penna, "margem do Igarapé Caquajó", S $1^{\circ} 57^{\prime}$ 37”, W 5137' 52", 30.I.2007, fr., M.M. Félix-daSilva et al. 124 (MG); Portel, FLONA Caxiuanã, Estação Científica Ferreira Penna, "margem do Igarapé Caquajó", S $1^{\circ} 57^{\prime} 37^{\prime \prime}$, W 513' 52", 17.II.2009, fr., M.M. Félixda-Silva et al. 566 (MG).

Additional specimen: Suriname. s.l., 23.VII.1908, fl., Tresleing 212 (MG).

Crudia bracteata occurs in igapó forests of the FLONA Caxiuanã. It can be recognized by the leaflets with attenuate apex and obovoid legumes. It is morphologically related to $C$. aequalis. For comments regarding the diagnostic characters between the species, see $C$. aequalis.

Crudia oblonga Benth., Bot. Voy. Sulphur 89. 1844

(Figure $3 \mathrm{H}$ and complementary illustrations in Vieira, 1990)

Trees ca. $20 \mathrm{~m}$ high. Branches fissured. Leaves with sericeous rachis, 5-6 cm long; leaflets 8 , oblong or obovate, base rounded, apex rounded, 1.8-4.2 $\times$ 1-2.5 cm. Flowers with hypanthium ca. $5.5 \mathrm{~mm}$ long; ovary oblongoid, tomentose, ca. $3 \mathrm{~mm}$ long, stipe tomentose. Legume oblongoid or elliptic, ca. 9.1 $\times 4.3 \mathrm{~cm}$.

Distribution: Guiana, Guiana Francesa, Venezuela, and Brazil: Amazonas, Pará, and Amapá (Vieira, 1990; Kearns, 1998; BFG, 2015, 2018).

Specimen examined: Brazil. Pará: Portel, FLONA Caxiuanã, Estação Científica Ferreira Penna, "rio Caxiuanã, próximo à praia da Fazenda", 28.VIII.2014, fr., C. Carvalho et al. 177 (MG).

Additional specimen: Brazil. Pará: Belém, "Horto do Museu, árvore 286", 1.VII.1975, fl., P. Cavalcante s.n. (RB 49727).

Crudia oblonga Benth. occurs in igapó forests of the FLONA Caxiuanã. It is morphologically close to $C$. bracteata, but can be recognized by the oblong leaflets with rounded apex, and oblong legumes (versus ovate leaflets with attenuate apex, and globoid or obovoid legumes in C. bracteata).

\section{Cynometra L., Sp. Pl. 1: 382.1753}

Trees. Branches striate, puberulent; stipules do not see. Leaves notably pinnate, paripinnate, rachis puberulent; leaflets 2, opposite, glands absent, ovate, base cuneate, apex emarginate-rounded or emarginate-caudate, venation acrodromous. Flowers differentiate into petals and sepals, campanulate hypanthium; stamens 10, filaments fused in the base, anthers rimose, oblong; staminodes absent; nectariferous disc absent; ovary oblongoid, ca. 2-3.5 mm long. Fruit bacoid legume, surface rugose, no-resinous. Seeds do not see.

Cynometra bauhiniaefolia Benth. J. Bot. (Hooker) 2(10): 99-100. 1840 (Figure 3I)

Trees ca. $6 \mathrm{~m}$ high. Leaves with rachis $0.4-0.7 \mathrm{~cm}$ long; leaflets with apex emarginate-rounded, 3 conspicuous 
veins, 3-5.5 $\times 1.5-3 \mathrm{~cm}$. Flowers with hypanthium ca. $4 \mathrm{~mm}$ long. Bacoid legume ca. $2.5 \times 2 \mathrm{~cm}$.

Distribution: Argentina, Chile, Peru, Colombia, Peru, Guatemala, French Guyana, Suriname, Venezuela, and Brazil: Amazonas, Pará, Roraima, Maranhão, and Goiás (Dwyer, 1958; BFG, 2015, 2018).

Specimen examined: Brazil. Pará: Portel, FLONA Caxiuanã, Estação Científica Ferreira Penna, "inventário 8", $1^{\circ} 44^{\prime} 30^{\prime \prime}$ S, 51 27' 44" W, 1.IX.2014, C. Carvalho et al. 202 (MG).

Additional specimen: Venezuela. Bolivar: locally frequent along Cano Coroso (Rio Caripo) between Rio Orinoco and Lago Coroso, 10.I.1956. J.J. Wurdack \& J. V. Monachino 41194 (RB).

Widely distributed in the Neotropic, C. bauhiniaefolia is found in the terra firme forests of the FLONA Caxiuanã. It is morphologically close to C. longicuspis, but can be recognized by the leaflets with 3 conspicuous veins and the apex emarginate-rounded (versus leaflets with 1 conspicuous vein and the apex emarginate-caudate in $C$. longicuspis Ducke).

Cynometra longicuspis Ducke, Bol. Tecn. Inst. Agron. (2): 11.1944 (Figure 3J)

Trees ca. $8 \mathrm{~m}$ high. Leaves with rachis $0.6 \mathrm{~cm}$ long; leaflets with apex emarginate and caudate, 1 conspicuous vein, 4.5-5.3 $\times 1.9-2 \mathrm{~cm}$. Flowers with hypanthium ca. $5 \mathrm{~mm}$ long. Bacoid legume ca. $2 \times 0.5 \mathrm{~cm}$.

Distribution: Brazil: Amazonas and Pará (Dwyer, 1958; BFG, 2015, 2018).

Specimen examined: Brazil. Pará: Portel, FLONA Caxiuanã, Estação Científica Ferreira Penna, "inventário 8", $1^{\circ} 44^{\prime} 30$ " S, 51 27' 44" W, 1.IX.2014, C. Carvalho et al. 206 (MG).

Cynometra longicuspis is putatively endemic to the Amazon rain forest and is found in terra firme forests in the FLONA Caxiuanã. It is morphologically close to $C$. bauhiniaefolia. For comments regarding the diagnostic characters between the species, see C. bauhiniaefolia.

\section{Eperua Aubl. Hist. Pl. Guiane 1: 369, pl. 142. 1775}

Eperua bijuga Mart. ex Benth., Fl. Bras. 15(2): 226. 1870 (for illustrations, see Félix-da-Silva et al., 2015) Trees 5-15 m high. Branches striate, glabrous; stipules leafshaped, falcate-ovate, glabrous, sessile, 7-15 × 3-11 mm. Leaves notably pinnate, paripinnate, rachis glabrous, 5-20 cm long; leaflets 10, opposite, glands present on the base, falcate-ovate, base rounded, apex acuminate, $8-20 \times 3.5-9 \mathrm{~cm}$, venation brochidodromous. Flowers differentiate into petals and sepals, hypanthium cupular, ca. $2 \mathrm{~mm}$ long; stamens 9, fused filaments, anthers rimose, oblong; staminodes 1; nectariferous disc absent; ovary oblongoid, 8-9 mm long. Fruit legume, obovoid, surface smooth, no resinous, 6-10 $\times 5-7 \mathrm{~cm}$. Seeds do not see.

Distribution: French Guyana and Brazil: Amazonas, Amapá, Pará, and Roraima (BFG, 2015, 2018; Reflora, 2020).

Specimens examined: Brazil. Pará: Melgaço, FLONA Caxiuanã, Estação Científica Ferreira Penna, "margem do rio Curuá”, 16.V.200, fl., J. Oliveira et al. 379 (MG); Melgaço, FLONA Caxiuanã, Estação Científica Ferreira Penna, "margem do rio Caxiuanã, mata de várzea", 14.X.1991, fr., A.S.L. Silva \& M.C. Silva 2392 (MG); Portel, FLONA Caxiuanã, "margem do igarapé Caquajó", 8.VII.2007, fr., M.M. Félix-da-Silva et al. 125 (MG, IAN).

Eperua bijuga is frequent in igapó forests of the FLONA Caxiuanã. The pinnate leaves and the falcateoblong leaflets up to $20 \mathrm{~cm}$ long resemble those of $M$. angustifolium (Benth.) R.S. Cowan. Eperua bijuga can be distinguished by the 4 leaflets with glands on the base, and stamens with fused filaments (versus 2 leaflets without glands on the base, and stamens with free filaments in M. angustifolium).

\section{Hymenaea L., Sp. Pl. 2: 1192.1753}

Trees. Branches striate or scaly, pubescent; stipules do not see. Leaves notably pinnate, with rachis glabrous or pubescent; leaflets 2, opposite, falcate, oblong or elliptic, base asymmetric rounded, apex acuminate or rounded, 
venation brochidodromous. Flowers differentiate into petals and sepals with campanulate hypanthium; stamens 10, free filaments, anthers rimose, oblong; staminodes absent; nectariferous disc present in the base of the corolla and stamens; ovary oblongoid or rhombic-ovoid. Fruit camara, surface rugose with resin glands, endocarp farinaceous with strong odor. Seeds lustrous-brownish, smooth.

\section{Hymenaea courbaril L. Sp. Pl. 2: 1192. 1753}

(Figure $3 \mathrm{~K}$ and complementary illustrations in

Lee \& Langenheim, 1975)

Trees to $20 \mathrm{~m}$ high. Branches striate. Leaves with rachis $0.7-1.1 \mathrm{~cm}$ long; leaflets with translucent glands present in the blade, elliptic-falcate, $3.5-10.5 \times 1.2-4 \mathrm{~cm}$. Flowers with hypanthium ca. $12 \mathrm{~mm}$ long; ovary 2-3.5 mm long. Camara piriform or oblongoid, lustrous-brown, 8-15 $\times 4-6 \mathrm{~cm}$. Seeds 5-8 per fruit.

Distribution: Belize, Caribe, Colombia, Chile, China, Costa Rica, Ecuador, El Salvador, French Guyana, Guatemala, Guiana, Honduras, Mexico, Nicaragua, Panama, Peru, Suriname, Taiwan, Venezuela, and Brazil: in all the country, except Santa Catarina and Rio Grande do Sul (Lee \& Langenheim, 1975; BFG, 2015, 2018).

Specimens examined: Brazil. Pará: Portel, FLONA Caxiuanã, Estação Científica Ferreira Penna, "grade do PPBio, trilha $E$, entre parcelas 21 e 22", $1^{\circ}$ 58' 58” S, $51^{\circ}$ 38' 16" W", 09.XII.2007, fr., M.M. Félix-da-Silva et al. 243 (MG); Portel, FLONA Caxiuanã, Estação Científica Ferreira Penna, "grade do PPBio, trilha C", $1^{\circ} 58^{\prime}$ 58” S, 51 38' 16” W, 22.VII.2008, fl., F. Bonadeu et al. 316 (MG).

The species is found in terra firme areas of the FLONA Caxiuanã and is commonly recognized as 'jatobá". It is morphologically close to $H$. intermedia Ducke, from which it can be distinguished by the shape of the leaflets (oblong in $\mathrm{H}$. intermedia), and mainly by the shape and color of the fruit: pyriform or oblongoid and lustrousbrown (versus fruits ovoid or rhomboid and opaquebrown in H. intermedia).
Hymenaea intermedia Ducke, Arch. Jard. Bot.

Rio de Janeiro 3: 92-93. 1922 (Figure 3L and complementary illustrations in

Lee \& Langenheim, 1975)

Trees to $30 \mathrm{~m}$ high. Branches scale. Leaves with rachis to $0.3 \mathrm{~cm}$ long; leaflets without translucent glands in the blade, oblong, 6.5-7.5 $\times 2.5-3.5 \mathrm{~cm}$. Flowers with hypanthium ca. $15 \mathrm{~mm}$ long, ovary to $3.5 \mathrm{~mm}$ long. Camara ovoid or rhomboid, opaque-brown, 6-7.5 $\times$ 3-4.5 cm. Seeds 1-3 per fruit.

Distribution: Colombia, Peru, Venezuela, and Brazil: all Amazon forest (BFG, 2015, 2018).

Specimens examined: Brazil. Pará: Portel, FLONA Caxiuanã, Estação Científica Ferreira Penna, "área da baía do rio Caxiuanã”, $1^{\circ} 46^{\prime} 32$ " S, 51²8' 47” W, 30.VIII.2015, fl., C. Carvalho et al. 190 (MG).

Additional specimen: Brazil. Rondônia: Porto Velho, "UHE de Samuel, rio Jamari", 11.II.1989, fr., U.N. Maciel et al. 1562 (MG).

Hymenaea intermedia is widely distributed in terra firme forest of the FLONA Caxiuanã and is also popularly called 'jatobá'. For comments regarding the diagnostic characters between the species, see H. courbaril.

\section{Macrolobium Schreb., Gen. Pl. 1: 30.1789}

Trees. Branches glabrous or pilose; stipules do not see. Leaves notably pinnate, paripinnate, or pseudoimparipinnate; leaflets 2-52, opposite, glands absent, oblong, lanceolate, falcate, elliptic, and flack, base asymmetric rounded, apex acuminate, venation brochidodromous. Flowers differentiate into petals and sepals, campanulate hypanthium, 1-3 mm long; stamens 3, free filaments, anthers rimose, oblong; staminodes absent; nectariferous disc absent; ovary oblongoid. Fruit legume, elliptic, ellipticobovoid, falcate, oblongoid or obovoid, laterally compress, surface striate, no-resinous. Seeds do not see.

For the taxonomic treatment and illustrations of Macrolobium spp. from FLONA Caxiuanã, see Félix-daSilva et al. (2013). 
Macrolobium angustifolium (Benth.)

R. S. Cowan, Mem. New York Bot.

Gard. 8(4): 314.1953 (for illustrations,

see Félix-da-Silva et al., 2013)

Distribution: Colombia, Peru, Venezuela, and Brazil: Amazonas, Mato Grosso, and Pará (Félix-da-Silva et al., 2013; BFG, 2015, 2018).

Specimens examined: Brazil. Pará: Melgaço, FLONA Caxiuanã, Estação Científica Ferreira Penna, "rio Curuá”, 21.V.2002, fl., J. Oliveira et al. 419 (MG); Melgaço, FLONA Caxiuanã, Estação Científica Ferreira Penna, "rio Puraquequara, margem", 29.X.1999, fl., A.S.L. Silva et al. 3649; Portel, FLONA Caxiuanã, "igarapé Caquajó", 30.I.2007, fr., M.M. Félix-da-Silva et al. 113 (MG).

Macrolobium angustifolium is broadly spread to the igapó forests of the FLONA Caxiuanã. The leaflets falcateoblong, of 6-18 cm long, make this species morphological close to M. bifolium (Aubl.) Pers. However, M. angustifolium differs of $M$. bifolium by the lower surface of the leaflets puberulent and ovary with trichomes only in the margins (versus lower surface of leaflets glabrous and ovary tomentose, in M. bifolium).

\section{Macrolobium bifolium (Aubl.) Pers.,}

Syn. Pl. 1: 39. 1805 (for illustrations,

see Félix-da-Silva et al., 2013)

Distribution: French Guyana, Guyana, Suriname, and Brazil: Acre, Amazonas, Amapá, Pará, Rondônia, and Roraima (Cowan, 1953; Félix-da-Silva et al., 2013; BFG, 2015, 2018).

Specimens examined: Brazil. Pará: Portel, FLONA Caxiuanã, "igarapé Caquajó", 30.I.2007, fr., M.M. Félixda-Silva et al. 116 (IAN, MG); Portel, FLONA Caxiuanã, "igarapé Caquajó", 1 57' 37" S, 51 37' 52" W, fl., M.M. Félix-da-Silva et al. 375 (MG).

Macrolobium bifolium occurs in the igapó forest of the FLONA Caxiuanã. It is morphologically similar to $M$. angustifolium. For the comments regarding the diagnostic characters between the species, see $M$. angustifolium.
Macrolobium brevense Ducke, Arch. Jard. Bot.

Rio de Janeiro 4: 50.1925 (for illustrations, see Félix-da-Silva et al., 2013)

Distribution: endemic to Brazil: Amazonas and Pará (Félixda-Silva et al., 2013; BFG, 2015, 2018).

Specimen examined: Brazil. Pará: Melgaço, FLONA Caxiuanã, Estação Científica Ferreira Penna, "estrada que vai para o trapiche”, 14.XII.1999, fr., A.S.L Silva et al. 3737 (MG).

Macrolobium brevense occurs in the terra firme forests of the FLONA Caxiuanã. The leaflets (14-52) oblong, sessile to sub-sessile, and legumes oblongoid and woody brings M. brevense closer to Macrolobium huberianum Ducke var. huberianum. However, it can be distinguished by the pilose branches compress legumes, $3.5-4.5 \mathrm{~cm}$ width (versus glabrous branches, legumes, $2.5-3.5 \mathrm{~cm}$ width, in M. huberianum var. huberianum).

Macrolobium campestre var. arboreum R. S. Cowan, Mem. New York Bot. Gard. 8(4): 301-302 (for illustrations, see Félix-da-Silva et al., 2013)

Distribution: endemic to Brazil: Acre, Amazonas, Pará, and Rondônia (BFG, 2015, 2018).

Specimens examined: Brazil. Pará: Melgaço, FLONA Caxiuanã, "local onde será construída a Estação Científica Ferreira Penna", 2-15.II.1991, A.S.L. Silva et al. 2227 (MG); Portel, FLONA Caxiuanã, "área de estudos do PPBio, parcela 19", 13.VII.2007, fr., M.M. Félix-da-Silva et al. 264 (IAN, MG).

Macrolobium campestre var. arboreum is distributed in the terra firme forest of the FLONA Caxiuanã. It can be morphologically distinguished from other members of Macrolobium by the leaf rachis up to $6.5 \mathrm{~cm}$ long, and leaflets 6 , elliptic, lanceolate to ovate, symmetrical, and 3-12 × 2-6 cm.

\section{Macrolobium huberianum Ducke var. huberianum,}

Arch. Jard. Bot. Rio de Janeiro 1(1): 26-27, pl. 8-9. 1915 (for illustrations, see Félix-da-Silva et al., 2013)

Distribution: Guyana and Brazil: Amazonas, Amapá, Pará, and Rondônia (Félix-da-Silva et al., 2013; BFG, 2015, 2018). 
Specimen examined: Brazil. Pará: Melgaço, FLONA Caxiuanã, "igarapé Grande", 09-24.VI.1995, fr., A.S.L. Silva 4371 (MG).

Macrolobium huberianum var. huberianum occurs in terra firme and igapó forests of the FLONA Caxiuanã. It is morphologically similar to $M$. brevense. For the comments regarding the diagnostic characters between the species, see the comments of $M$. brevense.

Macrolobium pendulum Willd. ex Vogel, Linnaea 11: 412. 1837 (for illustrations, see Félix-da-Silva et al., 2013) Distribution: species endemic to Brazil: Amazonas, Maranhão, and Pará (Félix-da-Silva et al., 2013; BFG, 2015, 2018).

Specimens examined: Brazil. Pará: Melgaço, FLONA Caxiuanã, Estação Científica Ferreira Penna, 15.X.1991, fl., A.S.L. Silva \& M.C. Silva 2424 (MG); Portel, FLONA Caxiuanã, "igarapé Caquajó", 19.XI.2007, fl., fr., M.M. Félix-da-Silva et al. 419 (IAN, MG).

Macrolobium pendulum occurs in igapó forest of the FLONA Caxiuanã. In the forest, it stands out because of the pendulous terminal inflorescence. It is also distinguished from other species of the genus by the ovate legumes.

\section{Peltogyne Vogel, Linnaea 11: 410. 1837}

Peltogyne venosa subsp. densiflora (Spruce ex Benth.) M.F. Silva, Acta Amazonica 6(1): 50. Supl. 1976 (for illustrations, see Félix-da-Silva et al., 2009)

Trees 5-8 m high. Branches striate, pubescent; stipules do not see. Leaves notably pinnate, rachis absent; leaflets 2, opposite, glands present in upper and lower surface, elliptic, falcate, base symmetrical rounded, apex acuminate, 7-18 $\times 4-9 \mathrm{~cm}$, venation brochidodromous. Flowers differentiate into petals and sepals, campanulate hypanthium, ca. $4 \mathrm{~mm}$ long; stamens 10, free filaments, anthers rimose, oblong; staminodes absent; nectariferous disc absent; ovary oblongoid, 4-8 mm long. Fruit legume, obovoid or oblique-oblongoid, surface smooth, noresinous, $2-4 \times 2-3 \mathrm{~cm}$. Seeds do not see.
Distribution: French Guyana, Guyana, Suriname, Venezuela, and Brazil: in all Amazonia, except in the state of Acre (Silva, 1976; BFG, 2015, 2018).

Specimens examined: Brazil. Pará: Melgaço, FLONA Caxiuanã, Estação Científica Ferreira Penna, 15.X.1991, fr., A.S.L. Silva et al. 2429 (MG); Melgaço, FLONA Caxiuanã, Estação Científica Ferreira Penna, "rio Caxiuanã", 14.X.1991, fr., A.S.L. Silva et al. 2413 (MG); Portel, FLONA Caxiuanã, "igarapé Caquajó", 30.I.2007, fr., M.M. Félix-da-Silva et al. 64 (MG, IAN).

Peltogyne venosa subsp. densiflora is widely distributed in the igapó forests in the FLONA Caxiuanã. The leaves with 2 leaflets and ovary oblongoid morphologically link $P$. venosa subsp. densiflora to Hymenaea spp. However, the former can be recognized by the symmetrical base of the leaflets and the fruit legume obovoid to obliqueoblongoid (versus leaflets with asymmetrical base and the fruit camara, ovoid to rhomboid in Hymenaea spp.). In addition, $P$. venosa subsp. densiflora is the only species in the FLONA Caxiuanã with the combination of one to two leaflets and legumes $2.5-3.5 \times 2.5-3 \mathrm{~cm}$.

\section{DIALIOIDEAE FROM CAXIUANÃ}

\section{Martiodendron Gleason, Phytologia 1: 141. 1935}

\section{Martiodendron parviflorum (Amshoff) R.C.} Koeppen, Brittonia 14(2): 202. 1962

(Figure 3M and complementary illustrations in Koeppen \& Iltis, 1962)

Trees 30-40 m high. Branches striate, puberulent; stipules deltate, tomentose, sessile, ca. $3.5 \times 1.5 \mathrm{~mm}$. Leaves notably pinnate, imparipinnate, rachis $11-20.5 \mathrm{~cm}$ long; leaflets 5-7, alternate, glands absent, oblong-ovate, base rounded or cordate, apex acute to acuminate, 5-14 × 3.5$7 \mathrm{~cm}$, venation brochidodromous. Flowers differentiate into petals and sepals, campanulate hypanthium, ca. $16 \mathrm{~mm}$ long; stamens 4, free filaments, anthers poricidal, sagittate; staminodes 1; nectariferous disc absent; ovary terete, to 


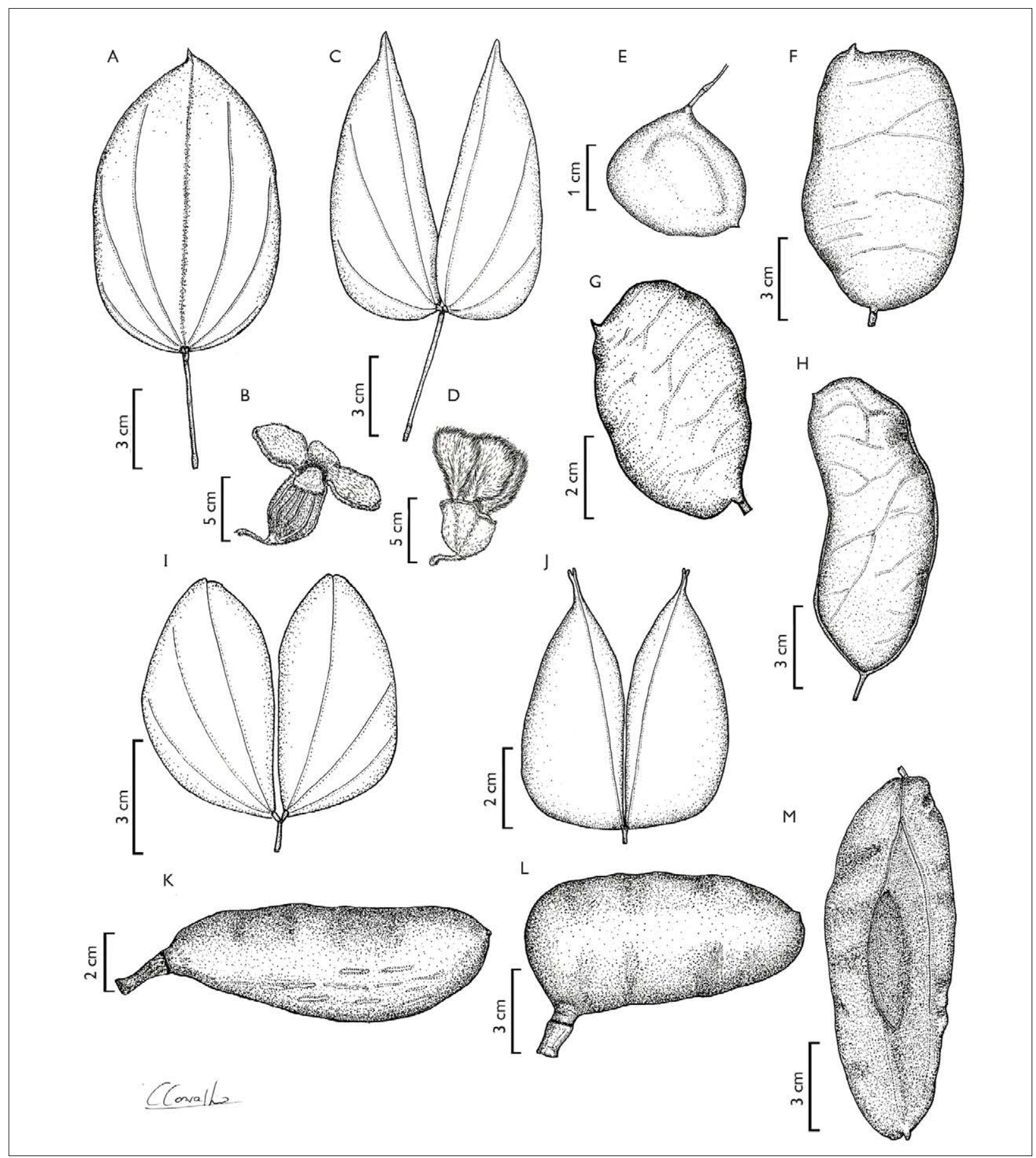

Figure 3. A-B) Schnella rutilans: A) leaf (Silva et al. 3116); B) flower, the petals were hidden (Carvalho 219); C-D) Schnella splendens - leaf (Carvalho 240); D) flower (Carvalho 259); E) Copaifera duckei - legume (Carvalho 262); F) Crudia aequalis - legume (Carvalho 296); G) Crudia bracteata - legume (Félix-da-Silva et al. 124); H) Crudia oblonga - legume (Carvalho et al. 179); I) Cynometra bauhiniaefolia - leaf (Carvalho et al. 202); J) Cynometra longicuspis - leaf (Carvalho et al. 206); K) Hymenaea courbaril - camara (Carvalho et al. 210); L) Hymenaea intermedia - camara (Maciel et al. 1562); M) Martiodendron parviflorum - samara (Carvalho et al. 167). Illustrations by Catarina S. Carvalho. 
$5 \mathrm{~mm}$ long. Fruit samara, oblongoid, surface striate, noresinous ca. $9 \times 5 \mathrm{~cm}$. Seeds terete, ca. $4 \times 2 \mathrm{~cm}$.

Distribution: French Guyana, Suriname, and Brazil: Amapá and Pará (Koeppen \& Iltis, 1962; BFG, 2015, 2018; Reflora, 2020).

Specimens examined: Brazil. Pará: Melgaço, FLONA Caxiuanã, "rio Curuá-Mirim, mata secundária com 18 anos de recrescimento", 16.I.1995, fr., L.C. Lobato et al. 625 (MG); Melgaço, FLONA Caxiuanã, Estação Científica Ferreira Penna, "próximo ao forno de cerâmica", 08.IX.2003, fr., M.A. Freitas 906 (MG); Portel, FLONA Caxiuanã, "próximo à base física da FLONA", 27.08.2014, fr., C. Carvalho 167 (MG).

Additional specimen: Brazil. Pará: Almeirim, "Estrada do Munguba (fazendinha)", 26.VI.1979, fl., N.T. Silva 5123 (MG).

Martiodendron parviflorum occurs in terra firme forests of the FLONA Caxiuanã, and it is recognized by the young leaflets reddish and the samara of the same color. It is morphologically close to Voacapoua americana Aubl. (Carvalho et al., 2020) because of the oblong-ovate leaflets. However, it can be distinguished by the leaf rachis without nectaries, anthers sagittate, poricidal, and the fruits samara (versus leaves with extrafloral nectaries in the rachis, anthers oblong, rimose, and the fruits legume, in $V$. americana).

\section{ACKNOWLEDGMENTS}

This study was conducted with the aid of a fellowship granted by the post-graduate program of the Museu Paraense Emílio Goeldi (MPEG) and Universidade Federal da Amazônia (UFRA). The study was financed in part by the Coordenação de Aperfeiçoamento de Pessoal de Nível Superior, Brazil (CAPES) - Finance Code 001, provided to first author (master's research fellowship) and the Programa Nacional de Apoio e Desenvolvimento da Botânica (PNADB). We thank the Instituto Chico Mendes de Conservação da Biodiversidade (ICMBio) for granting the botanical collection license (Sisbio 43489-1). We thank M. Sc. Antonio Sérgio Lima da Silva to provide important bibliographic references to identify the species; and we particularly thank Dr. Danilo Neves, who made possible the first field work in the FLONA Caxiuanã. We also would like to thank the Estação Científica Ferreira Penna (ECFPn-MPEG) and all the staff involved during our stay at the field station, especially Sr. Joca who made it possible to conduct the field work; and the then director of the ECFPn-MPEG, Dr. Leandro Valle Ferreira. Finally, we also thank Janet Reid for the language revision and Erlane J. Cunha for preparing of the map.

\section{REFERENCES}

BARROSO, G. M., M. P. MORIM, A. L. PEIXOTO \& C. L. F. ICHASO, 1999. Leguminosae. In: G. M. BARROSO, M. P. MORIM, A. L. PEIXOTO \& C. L. F. ICHASO (Ed.): Frutos e sementes: morfologia aplicada à sistemática de Dicotiledôneas: 168-221. UFV, Viçosa.

BENTJE, H., 2010. The Kew: plant glossary: 1-165. Royal Botanical Gardens, Kew.

BONADEU, F. \& J. U. M. SANTOS, 2013. Contribuição ao conhecimento dos gêneros da tribo Ingeae ocorrentes em uma Floresta Nacional da Amazônia brasileira. Rodriguésia 64: 321-336. DOI: https://doi.org/10.1590/S2175-78602013000200009

BRAZILIAN FLORISTIC GROUP(BFG), 2015. Growing knowledge: an overview of Seed Plant diversity in Brazil. Rodriguésia 66: 10851113. DOI: https://doi.org/10.1590/2175-7860201566411

BRAZILIAN FLORISTIC GROUP (BFG), 2018. Brazilian Flora 2020: innovation and collaboration to meet Target 1 of the Global Strategy for Plant Conservation GSPC. Rodriguésia 69: 1513-1527. DOI: https://doi.org/10.1590/2175-7860201869402

BRUMMITT, R. K. \& C. E. POWELL, 1992. Authors of plant names: 1-732. Whitstable, Great Britain.

CARDOSO, D., T. SÄRKINEN, S. ALEXANDER, A. M. AMORIM, V. BITTRICH, M. CELIS, D. C. DALY, P. FIASCHI, V. A. FUNK, L. L. GIACOMIN, R. GOLDENBERG, G. HEIDEN, J. IGANCI, C. L. KELLOFF, S. KNAPP, H. C. LIMA, A. F. P. MACHADO, R. M. SANTOS, R. MELLO-SILVA, R. F. A. MICHELANGELI, J. MITCHELL, P. MOONLIGHT, P. L. R. MORAES, S. A. MORI, T. S. NUNES, T. D. PENNINGTON, J. R. PIRANI, G. T. PRANCE, L. P. QUEIROZ, A. RAPINI, R. RIINA, C. A. V. RINCON, N. ROQUE, G. SHIMIZU, M. SOBRAL, J. R. STEHMANN, W. D. STEVENS, C. M. TAYLOR, M. TROVÓ, C. VAN DEN BERG, H. VAN DER WERFF, P. L. VIANA, C. E. ZARTMAN \& R. C. FORZZA, 2017. Amazon plant diversity revealed by a taxonomically verified species list. Proceedings of the National Academy of Sciences 114: 1069510700. DOI: https://doi.org/10.1073/pnas.1706756114 
CARVALHO, C. S., 2016. Estudos florísticos em Leguminosae na FLONA de Caxiuanã, Pa, Brasil: 1-143. Dissertação (Mestrado em Ciências Biológicas) - Museu Paraense Emílio Goeldi/Universidade Federal Rural da Amazônia, Belém, Pará.

CARVALHO, C. S., M. P. MORIM \& J. U. M. SANTOS, 2020. Sinopse taxonômica de Caesalpinioideae Leguminosae na Floresta Nacional de Caxiuanã, Pará, Brazil. Rodriguésia 71: e02982018. DOI: http://dx.doi.org/10.1590/2175-7860202071067

COWAN, R. S., 1953. A taxonomic revision of the genus Macrolobium Leguminosae-Caesalpinioideae. Memoirs of the New York Botanical Garden 8: 257-342.

DUCKE, A., 1949. Notas sobre a Flora Neotropica 11. As Leguminosas da Amazônia brasileira. Boletim Técnico do Instituto Agronômico do Norte 18: 1-248.

DWYER, J. D., 1958. A new word species of Cynometra. Annals of the Missouri Botanical Garden 45: 313-345.

ELLIS, B., D. C. DALY, L. J. HICKEY, K. R. JOHNSON, J. D. MITCHELL, P. WILF \& S. L. WING, 2009. Manual of leaf architecture: 1-190. New York Botanical Garden, New York.

FÉLIX-DA-SILVA, M. M., M. N. C. BASTOS \& E. S. C. GURGUEL, 2009. Aspectos taxonômicos e morfológicos do processo germinativo e da plântula de Peltogyne venosa subsp. densiflora (Spruce ex Benth.) M.F. Silva (Leguminosae - Caesalpinioideae). Boletim do Museu Paraense Emílio Goeldi. Ciências Naturais 4(3): 291-392.

FÉLIX-DA-SILVA, M. M., M. N. C. BASTOS \& E. S. C. GURGUEL, 2013. Macrolobium Schreb. Leguminosae, Caesalpinioideae na Floresta Nacional de Caxiuanã, Pará, Brazil. Boletim do Museu Paraense Emílio Goeldi. Ciências Naturais 8(1): 75-93.

FÉLIX-DA-SILVA, M. M., M. N. C. BASTOS \& E. S. C. GURGUEL, 2015. Contribuição ao conhecimento de Eperua bijuga Mart. ex Benth. (Leguminosae: Caesalpinioideae). Biota Amazônia 5(1): 22-26.

FIDALGO, O. \& V. L. R. BONONI, 1984. Técnicas de coleta, preservação e herborização do material botânico: (4): 1-62. Instituto de Botânica, São Paulo.

FLORA DO BRASIL 2020, 2021. Jardim Botânico do Rio de Janeiro. Available at: http://floradobrasil.jbrj.gov.br/. Accessed on: 08 April 2021.

FORZZA, R. F., J. F. A. BAUMGRATZ, C. E. M. BICUDO, D. A. L. CANHOS, A. A. C. CARVALHO, M. A. NADRUZ COELHO, D. P. COSTA, M. G. HOPKINS, P. LEITMAN, L. G. LOHMANN, E. N. LUGHADHA, L. C. MAIA, G. MARTINELLI, M. MENEZES, M. P. MORIM, A. L. PEIXOTO, J. R. PIRANI, J. PRADO, L. P. QUEIROZ, S. SOUZA, V. C. SOUZA, J. R. STEHMANN, L. S. SYLVESTRE, B. M. T. WALTER \& D. C. ZAPPI, 2012. New Brazilian floristic list highlights conservation challenges. Bioscience 62: 39-45. DOI: https://doi.org/10.1525/bio.2012.62.1.8
HERBÁRIO VIRTUAL DA FLORA E DOS FUNGOS (INCT), 2020. Available at: http://inct.splink.org.br/. Accessed on: 26 August 2020.

INSTITUTO CHICO MENDES DE CONSERVAÇÃO DA BIODIVERSIDADE (ICMBio), 2020. Available at: http://www. icmbio.gov.br/portal/flona-de-caxiuana. Accessed on: 28 August 2020.

JSTOR - GLOBAL PLANTS DATABASE (JSTOR), 2020. Available at: https://plants.jstor.org/. Accessed on: 28 August 2020.

KEARNS, D. M., 1998. Crudia. In: J. A. STEYERMARK, P. E. BERRY \& B. K. HOLST (Ed.): Flora of Venezuelan Guayana: 4: 48-49. Missouri Botanical Garden Press, St. Louis.

KOEPPEN, R. \& H. ILTIS, 1962. Revision of Martiodendron (Cassieae, Caesalpiniaceae). Brittonia 14(2): 191. DOI: https:// doi.org/10.2307/2805226

LEE, Y. T. \& J. H. LANGENHEIM, 1975. Systematic of the genus Hymenaea (Leguminosae - Caesalpinioideae, Detarieae): 1-101. University California (Publications in Botany, v. 69), Bekerley.

LEGUME PHYLOGENY WORKING GROUP (LPWG), 2017. A new subfamily classification of the Leguminosae based on a taxonomically comprehensive phylogeny. Taxon 66: 44-77. DOI: https://doi.org/10.12705/661.3

LEWIS, G., B. SCHRIRE, B. MACKINDER \& M. LOCK (Ed.), 2005. Legumes of the world: 1-577. Royal Botanical Garden, Kew.

LOYOLA, R., N. MACHADO, D. VILA NOVA, E. MARTINS \& G. MARTINELLI, 2014. Áreas prioritárias para conservação e uso sustentável da flora brasileira ameaçada de extinção. Andrea Jackobsson, Instituto de Pesquisas Jardim Botânico do Rio de Janeiro, Rio de Janeiro.

MARTINS-DA-SILVA, R. C. V., J. F. PEREIRA \& H. C. LIMA, 2008. O gênero Copaifera (Leguminosae - Caesalpinioideae) na Amazônia brasileira. Rodriguésia 59(3): 455-476. DOI: https:// doi.org/10.1590/2175-7860200859304

NOGUEIRA, C., P. H. VALDUJO, A. PAESE, M. B. RAMOS NETO \& R. B. MACHADO, 2009. Desafios para a identificação de áreas para a conservação da biodiversidade. Megadiversidade 5: 43-53.

REFLORA - HERBÁRIO VIRTUAL (REFLORA), 2020. Available at: http://reflora.jbrj.gov.br/reflora/herbarioVirtual/. Accessed on: 26 February 2020.

SILVA, M. F., 1976. Revisão taxonômica do gênero Peltogyne Vogel Leguminosae-Caesalpinioideae. Acta Amazonica 6(1): supplement.

TER STEEGE, H. et al. 2013. Hyperdominance in the Amazonian tree flora. Science 342: 1243092. DOI: http://doi.org/10.1126/ science.1243092 
THIERS, B., 2021. Index Herbariorum: A global directory of public herbaria and associated staff. New York Botanical Garden's Virtual Herbarium. Available at: http://sweetgum.nybg.org/ih/. Accessed on: 06 August 2020.

TRETHOWAN, L. A., R. P. CLARK \& B. A. MACKINDER, 2015. A synopsis of the neotropical genus Schnella (Cercideae: Caesalpinioideae: Leguminosae) including 12 new combinations. Phytotaxa 204(4): 237-252. DOI: http://dx.doi.org/10.11646/ phytotaxa.204.4.1

TROPICOS.ORG (2020). Missouri Botanical Garden. Available in: http://www.tropicos.org. Accessed on 07 September 2020.
VIEIRA, M. A. G., 1990. Contribuição ao estudo taxonômico do gênero Crudia (Caesalpinioideae) na Amazônia brasileira. Boletim do Museu Paraense Emílio Goeldi, Série Botânica 6(1): 82-112.

WUNDERLIN, R., 1998. Bauhinia. In: J. A. STEYERMARK, P. E. BERRY \& B. K. HOLST (Ed.): Flora of Venezuelan Guayana: 4: 5-13. Missouri Botanical Garden Press, St. Louis.

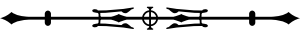

